\title{
Implications of Disagreement Between Self-Reporting and Objective Measures: A Scoping Review
}

\author{
Hilal Salim Al Shamsi ${ }^{1}$, Abdullah Ghthaith Almutairi ${ }^{2}$ \& Sulaiman Salim Al Mashrafi ${ }^{3}$ \\ ${ }^{1}$ Directorate of Planning and Studies, Directorate General of Planning and Studies, Al-Buraimi Governorate, \\ Ministry of Health, Oman \\ ${ }^{2}$ Quality Department, Prinice Nasser Hospital, Al-Ghat Province, Ministry of Health, Saudi Arabia \\ ${ }^{3}$ Directorate General of Planning and Studies, Department of Health Information and Statistics, Muscat, Ministry \\ of Health, Oman \\ Correspondence: Hilal Salim Al Shamsi, Directorate of Planning and Studies, Directorate General of Health \\ Services, Al-Buraimi Governorate, Ministry of Health, Oman.
}

\author{
Received: April 9, 2018 Accepted: May 17, 2018 Online Published: May 25, 2018 \\ doi:10.5539/gjhs.v10n6p199 URL: https://doi.org/10.5539/gjhs.v10n6p199
}

\begin{abstract}
Introduction: Researchers and health specialists generally collect data and information about chronic diseases from self-reports. However, the accuracy of self-reports has been questioned as they depend on the respondents' ability to recall information and their understanding of pathological conditions. Therefore, an objective diagnosis is usually regarded as a more accurate indication of the presence of diseases.
\end{abstract}

Objective: A scoping review will examine the extent of the disagreement between self- reports and objective measures, focusing on the implications of this disagreement in terms of indicators of physical and emotional health as well provision and planning of health services.

Method: There are few publications on the impact of disagreements between self-reporting and objective measures. In this case, a scoping review was chosen as an efficient tool to explore the issue, due to the limited amount of available evidence. This review was conducted in two major research databases: Scopus and Medline databases. The criteria of the study included all genders, age groups, and geographic areas. The source of information for the scoping review included existing literature such as guidelines, letters, meta-analyses, systematic reviews, and primary research studies.

Result: In the 12 studies, the total participants were 155,939 and each study's sample size ranged from 77 to 118,553 . Four out of twelve studies showed a significant difference between self-reported ailments and objective diagnosis for (kappa $=0.17$ to 0.3 ), whereas the agreement was moderate for the utilization of health services and quality of ambulatory care (kappa $=0.43$ to 0.5 ), however, the agreement on whether counselling and referrals were needed was low (kappa $=0.3,95 \%$ CI [0.3-0.3]). The disagreements between self-report and objective measures had implications regarding prevalence of diseases (20\% less by self-reported) or risk factors (such as physical activity [PA]), costs of treatments (15 EUR high by reports), risk factors such as car accidents for elderly (useful field of view in elderly drivers was a risk over four times larger than obtained from self-reported $[\mathrm{OR}=13.7 \mathrm{vs}$ $\mathrm{OR}=3.4]$ ), and utilization of health services ( $34.1 \%$ higher by reported).

Conclusion: In most health domains, we found there was low to moderate disagreement between self-reporting and objective measures for diagnosing illnesses and utilization of health services. The prevalence of disease was lower when self-reported, while the utilization of health services and cost of health services were higher when self-reported than when objectively measured. This disagreement has implications regarding the increasing the cost of health services and provides a misleading basis for health planning.

Keywords: chronic diseases; diabetes, hypertension; self-reporting; accurate measure; objective measure; agreement; disagreement; impact and effect.

\section{Introduction}

Chronic diseases are a group of diseases that could be long-lasting and have persistent effects. The Department of Health (2017) stated that chronic diseases have a broad range of complex and chronic health conditions over the spectrum of sickness including trauma, disability, mental illness, and genetic disorders in Australia. This group of diseases shares common risk factors such as ageing and changing lifestyles. These factors become increasingly common and now lead to most of the burden of ill health. The Australian Institute of Health and Welfare (2014) 
pointed out that for the purpose of simplification, chronic disease can be classed in four major disease groups cancers, cardiovascular diseases, diabetes, and chronic obstructive pulmonary disease.

Diabetes and hypertension are the two main chronic diseases that contribute considerably to the burden of disease globally. World Health Organization [ WHO ] (2011) states that these diseases are associated with high morbidity, mortality, and disability. Moreover, they are significant risk factors for heart failure, coronary artery disease, and cerebrovascular disease (Mohan, Seedat, \& Pradeepa, 2013). Mathers and Loncar (2006)predict that diabetes will be the seventh leading cause of death and hypertension will be the eleventh leading cause of death by 2030.The distribution of these two diseases increased in the last decades in the world and they also lead to many complications of other non-communicable diseases. The global prevalence of diabetes increased from 108 million cases in 1980 to 422 million cases in 2014 (WHO, 2016), while the number of hypertension cases increased from 600 million in 1980 to 1 billion in 2008 (WHO, 2013). Chow et al. (2013) highlight that hypertension is a risk factor for cardiovascular disease and is associated with approximately 7.6 million annual deaths worldwide. Diabetes, on the other hand, is the main cause of kidney failure, stroke, heart attacks, lower limb amputation, and blindness (WHO, 2016). The World Health Organization (2016) states that this disease was the direct cause of approximately 1.5 million deaths in 2012. Furthermore, diabetes can increase the risk of developing hypertension. Nishikawa, Edelstein, and Brownlee (2000) state that diabetes can also damage arteries, which causes hypertension and others serious complications such as heart attacks and kidney failure.Meanwhile, hypertension can cause many complications such as heart attack, blindness, cognitive impairment and kidney failure (WHO, 2015). In other words, each disease is a risk factor for the other. For example, one United Kingdom-based study shows that controlling blood pressure can reduce strokes and deaths related to diabetes (Adler et al., 2000). In brief, these diseases are major public health challenges worldwide and are associated with each other.

The burden of non-communicable diseases, such as hypertension and diabetes, has increased in Oman over the last two decades; several studies document that economic development has increased the risk factors for non-communicable diseases such as lifestyle (Al Riyami et al., 2012). The authors also highlight that the Oman World Health Survey 2008 found the prevalence of diabetes and hypertension to be $12.3 \%$ and $40.3 \%$ in Oman, respectively. Similarly, the 2000 National Health survey reports the prevalence of diabetes has increased from $8.3 \%$ in 1991 to $11.6 \%$ in 2000 , an increase of about $40 \%$ over a single decade (Al Shafaee et al., 2008). Thus, economic development contributed to increasing the prevalence of these diseases and their burden in Oman.

Epidemiologic studies commonly use self-report questionnaires to obtain health data. This data could be collected by any one of several self-report techniques, including telephone interviews, face to face interviews, or mail back questionnaires. Self-report questionnaires are efficient and simple to obtain the opinions and views directly from the participant (Paulhus, Vazire, Robins, Fraley, \& Krueger, 2007). Nevertheless, this method has some disadvantages: participants fail to offer accurate responses due to impression management, poor memory, mood or cognitive biases, and social bias (McDonald, 2008).T! he accuracy of this type of method could vary from one study to another, depending on the characteristics of the nature of the disease, a population, and participants' health symptoms or status (Huerta, José Tormo, Egea-Caparrós, Ortolá-Devesa, \& Navarro, 2009). Likewise, the accuracy of self-report depends on both knowledge of health related information and also recall ability of the participant (Goldman, Lin, Weinstein, \& Lin, 2003). Briefly, collecting health data by self-reports could be inexpensive and efficient; however, its accuracy relies on participants' knowledge and ability.

Based on this self-reported information decisions on planning and policies are made. While many studies show substantial disagreement between self-reports and objective measures for diagnosis of chronic diseases, the understanding of implication for this disagreement on health planning or health status is not been sufficiently examined. Sibley and Glazier (2009) pointed out that the disagreement between self-reported and objective measures could affect the health planning, which could lead to inappropriate specification of health service needs, services, accessibility and acceptability. The implications of this disagreement could be varied from specific disease to other whether on health planning or health status and there is need for further studies to understand more (Merkin et al., 2007). In this paper, a scoping review will examine the extent of the disagreement between selfreports and objective measures for diagnosis of chronic diseases, focusing on the implications of this disagreement in terms of indicators of physical and emotional health as well provision and planning of health services. Finally, some recommendations will be suggested to address these impacts.

\section{Methods}

There are few publications on the implications of disagreement between self-reporting and objective measures. In this case, a scoping review is considered an efficient tool to explore an issue with a limited amount of available evidence (Peters et al., 2015). Other types of reviews are designed to answer specific research/ study questions. For instance, a systematic review examines the efficacy of an intervention on a particular set of results (Arksey \& O'Malley, 2005). Meanwhile, the scoping review is utilized to map the main concepts that support a research area, which can identify gaps in the knowledge of research base and present the evidence in scope to inform and address practice (Peters et al., 2015). Therefore, scoping review is useful for a complex topic and less published studies. 


\subsection{Search Strategy}

Studies were searched in Scopus and Medline databases, accepting all English-language studies published after 1990. The searched keyword terms included "chronic diseases or diabetes or hypertension" and "self-reporting" and "accurate measure or objective measure" and "agreement or disagreement" and "impact or effect". The search terms were sufficiently broad to capture relevant articles.

\subsection{Inclusion Criteria}

The criteria of the study included both genders, all age groups and any geographic area. The source of information for the scoping review included any existing literature such as guidelines, letters, meta- analyses, systematic reviews, and primary research studies. Furthermore, studies which examine the disagreement between self-reports and objective measures for diseases and non-diseases were included.

\subsection{Data Presentation}

Collection data will be shown in tables. The first table will summarize the main characteristics included in these of collection studies to give the overall idea about these studies. Other tables will present findings from these 12 studies which help for comparative analysis.

\subsection{Data Extraction}

General characteristics for each study were extracted. These data include the author, country, data collection for self-report, study design, sample size, percentage of females out the total of participants, the aim of study, age of participants, diseases, and objective measure - data collection. Moreover, measures of association for each study, attrition rate, and the main findings were presented in a separate table.

\section{Results}

Figure 1 shows the process of chosen articles included in this study. Overall, 541 studies were selected from Scopus database $(\mathrm{n}=189)$ and Medline $(\mathrm{n}=352)$ from which 130 studies remained after duplicates and non-English language articles were removed. Out of these studies, 28 studies were excluded after screening because the abstract did not mention a self-reporting method. After full-text articles were assessed for eligibility 64 articles were excluded because no objective measure was available. In addition, eleven articles had unclear agreement between self-reporting and objective measures, and sixteen articles did not report any impact of the disagreement between them. Consequently, 12 studies were included in this study.

\subsection{General Characteristics of Included Studies}

Table 1 presents a summary of the main characteristics of twelve studies included in this study. Seven of the twelve studies were published in the United States, one in the United Kingdom, one in Germany, one in the Netherlands, one in Taiwan, and on in six other countries (Belgium, the Czech Republic, Denmark, Spain, the United Kingdom, and the United States). The majority of studies that were included were published between 2007 and 2015. The total participants were 155,939 and the sample size ranged from 77 to 118,553 in all the studies. Two studies had more than ten thousand participants. The percentage of female participants ranged from $26 \%$ to $66 \%$ in these studies. Six of the twelve studies had participants age 55 and above, whereas the participants in another five studies were 18 years and above, and one study had participants age 12 years and older.

The majority study design used in all twelve studies was a cross-sectional study. Nine studies used face-to-face interviews in collecting data for self-reports, two studies used online questionnaires, and one study used a telephone interview method. Objective measures were calculated by using secondary data in all twelve studies.

\subsection{Extent of Agreement Between Self-Reporting and Objective Measures}

The overall agreement between self-reporting and objective measures varies from weak to moderate in these twelve studies. In four out of twelve studies, the overall agreement was a weak for disease prevalence with kappa $=0.17$ to 0.3 (Daniels et al., 2011; Gao et al., 2015; Sakshaug et al., 2014; Van den Akker et al., 2015). However, the agreements within variables were low to high. The overall agreement between self-diagnosis and objective diagnosis for presence of several chronic illnesses (such as diabetes, migraine, heart disease and rheumatoid arthritis) was low (kappa $=0.17,95 \% \mathrm{CI}[0.21-0.13]$ ), whereas the lowest agreement was in rheumatoid arthritis (kappa $=0.17,[0.11-0.23])$ and the highest in the diagnosis of diabetes (Kappa $=0.86,[0.83-0.87])$ (Van den Akker et al., 2015). In addition, the overall agreement was moderate for the utilization of health services (kappa $=0.43$ to 0.5) (Cunningham et al., 2007; Tisnado et al., 2006; Wu et al., 2014) and risk factors, such risk of accidents $($ kappa $=0.45)$ (McGwin et al., 1998) in other studies discussed in this scoping review. Furthermore, the agreement within their variables varies between weak to moderate. The overall agreement for quality of ambulatory care was moderate $(\mathrm{kappa}=0.5$ ); however, the agreement for counseling and referrals was low (kappa $=0.3,95 \%$ $\mathrm{CI}[0.3-0.3])$, and so was medication use (kappa $=0.6,95 \% \mathrm{CI}[0.5-0.7])$, but both diagnoses and clinical services delivered (kappa $=0.6,95 \% \mathrm{CI}[0.05-0.6])$. 


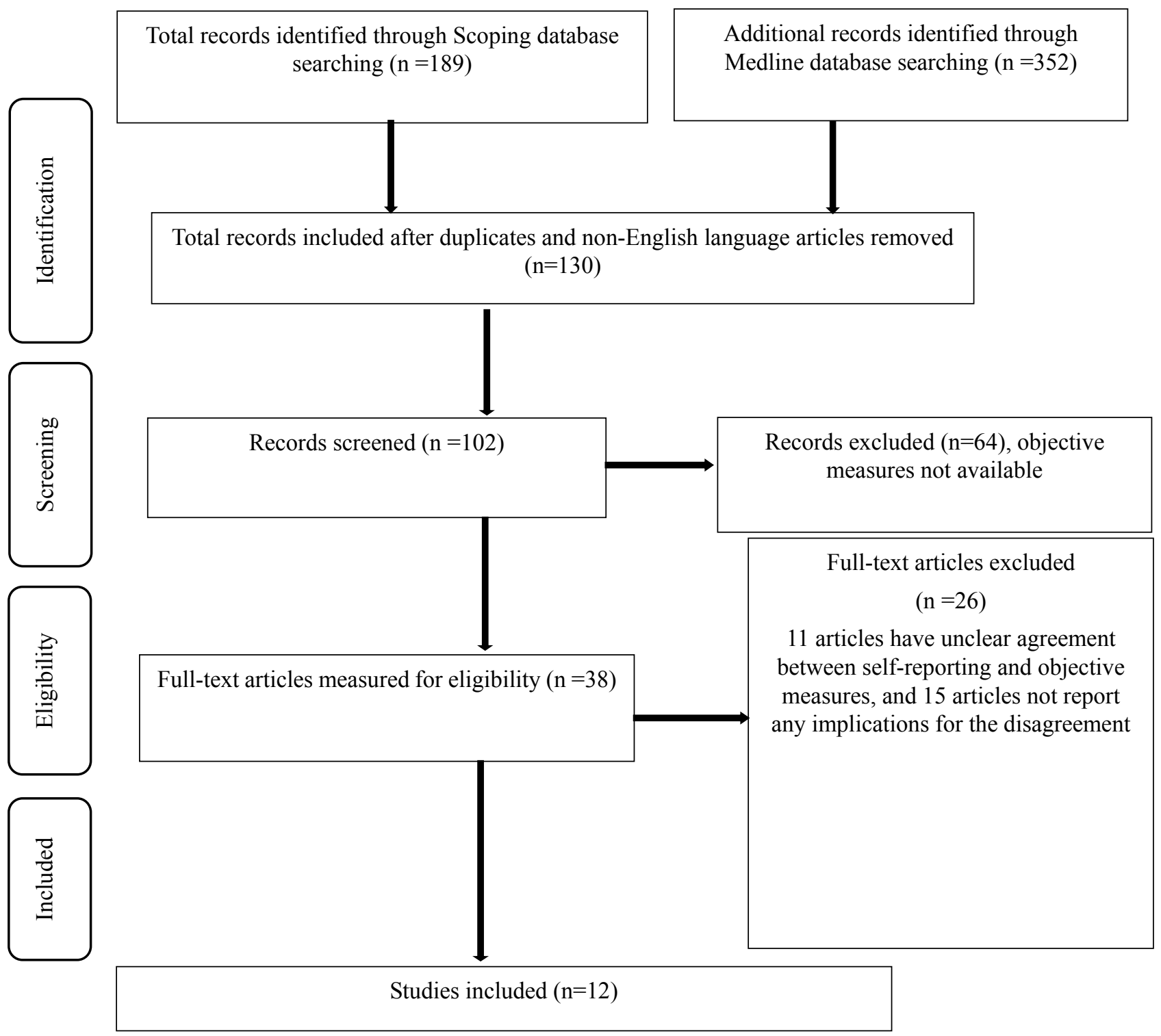

Figure 1. The process of selecting the ten articles which are included in this study

\subsection{Implications of Disagreement Public Health and Health Care Services Utilization}

We examined the implications of the disagreement between self-report and objective measures onprevalence of conditions or risk factors (such as PA), cost of treatments, risk factors (such as car accidents for elderly), and utilization of health services (Table 3). Five of twelve studies pointed out the prevalence of illnesses was $6 \%$ to $20 \%$ lower by self-reporting (Gao et al., 2015; McAdams et al., 2007; Sakshaug et al., 2014; Tisnado et al., 2006; Van den Akker et al., 2015). The low reporting of illnesses had potentially impacted the increasing of cost of health care, misrepresenting the need for health care spending and utilization for diseases, and giving a low number of cases than the objectively measuring cases (less about 20\%). Two studies found that participants self-reported sufficient PA 33\% more often than was accurate (Cerin et al., 2016; Downs et al., 2014). The sitting time recorded was three hours more than self-reports indicated (Cerin et al., 2016), which means that students were more sedentary than reported. In addition, the cost of mental health service was 15 EUR (95\% CI -434 to 405) higher in self-reports (Heinrich et al., 2011). In contrast, the useful field of view in elderly drivers was over four times larger than that obtained from self-report $(\mathrm{OR}=13.7 \mathrm{vs} \mathrm{OR}=3.4)$. This observation impacts vision during driving, which increases the risk of car accidents (McGwin et al., 1998). Furthermore, the optimal ambulatory care utilization in HIV cases ( $\geq 2$ visits for 6 months) was $34.1 \%$ higher in self-reports, which impacts evaluations of this service and when and how to improve this service for HIV patients (Cunningham et al., 2007). The planning for budget of health insurance was misled because the inaccuracy of prevalence of health conditions (ranging from behavioral health diagnoses to heart disease to arthritis) was lower in self-reports than claims 
records show (1.6\% vs 6.8\%, and 3.9\% vs $8.2 \%$, and 3.3\% vs 7.0\%, respectively) (Wu et al., 2014).

\section{Discussion}

This scoping review sought to evaluate the extent of the disagreement between self-report and objective measures, and examine the implications by reviewing the data from twelve studies that met the selection criteria. In most health fields, the agreement was weak to moderate (Table 2). We found that the agreement was weak for disease diagnosis, while the agreement for utilization of health services was moderate. Our findings also showed the prevalence of health conditions and some risk factors (such as a lack of PA) were low when self-reported. Meanwhile, costs of health services, other risk factors (such as car accidents for elderly), and utilization of health service were higher when self-reported than when measured objectively. We found that this disagreement had an impact on the cost of health services, risk factors (such as risk of accidents for elderly drivers), and planning for health services utilizations.

In this review, the overall agreement was weak for prevalence of health conditions in these twelve studies. The statistical difference between self-reports and objective measures could be explained by low awareness of these diseases because of a lack educational effort to spread awareness about them in the general population (Control $\&$ Prevention, 2003; Norris et al., 2002). Likewise, Merkin et al. (2007) highlighted that a lack of awareness about various health conditions and few educational interventions can be responsible for the discrepancy between self-reports and objective measures. In addition, self-reports and objective measures moderately agreed on how frequently patients utilized health services, data which could be affected by the types of services available to patients and the population sample reviewed. This level of agreement could be caused by different factors such as type of services, utilization frequency of services, and population sample (Bhandari \& Wagner, 2006).

The disagreement between self-reporting and objective measures for the prevalence of health conditions leads to inaccurate estimations, which have an impact on community health and planning for health services budgeting. Our findings showed that in most studies estimating the prevalence of health conditions, the estimation was $20 \%$ lower when self-reported than when measured objectively. Consequently, this disagreement contributed increased the cost of health services by 15 EUR, misleading health services budgeting and expected utilization, and leading to inaccurate assessments of future health trends. The disagreement between medical records and self-reported estimations of health conditions' prevalence leads to substantial differences in estimated parameters of health conditions and also affected planning of health services (Barbara, Loeb, Dolovich, Brazil, \& Russell, 2012).

Accurate assessment of PA is required to assess changing and improving levels of PA (Prince et al., 2008). Our findings showed, as the result of the discrepancy between self-reported PA and objectively measured PA, PA is $33 \%$ lower than self-reported, which means over 2 hours daily more sedentary than reported. Downs et al. (2014) stated the discrepancy in self-assessment of PA has a negative impact on implementing strategies for increasing physical activity levels the population.

It is important to bridge the gap between self-reports and claims records because the self-reported questionnaires are the most common method of collecting information in health care services. The agreement for volume of health care services utilization and the cost of these services was moderate in this review. The impact of this disagreement was increased cost of health services by 15 EUR and difficult to evaluate the HIV care services (HIV care service utilization was high over $30 \%$ by reported). Moreover, the impact of this disagreement on health services was misleading health insurance planning because of the lower number self-reported of chronic diseases than by claim records.

Some limitations of this review needed to be considered. First, most of the studies were cross-sectional which limited our ability to assess the impact of disagreements between self-report and objective measures for chronic ailments on other predictors. Second, the study also drew from studies discussing many countries; the US and the UK for example have very different health care systems and may measure or plan for health conditions in the population very differently.

\section{Conclusion}

We found that there were low to moderate agreements between self-reported and objective measures for diagnosing diseases and utilization of health services. The prevalence of health conditions was low when self-reported, while the utilization of health services, and cost of health services were higher by self-report than objective measures. This disagreement has implications on increasing the cost of health services and provides misleading basis for long term health care planning. More research for investigating the impact of measures tools with representative sample size for a population is needed. 


\section{Competing Interests Statement}

The authors declare that there are no competing or potential conflicts of interest.

\section{References}

Adler, A. I., Stratton, I., Neil, H., Yudkin, J., Matthews, D., Cull, C., . . Holman, R. (2000). Association of systolic blood pressure with macrovascular and microvascular complications of type 2 diabetes (UKPDS 36): prospective observational study. $\mathrm{Br} . \quad \mathrm{Med} . \quad \mathrm{J} ., \quad$ 321(7258), 412-419.https://doi.org/10.1136/bmj.321.7258.412

Al Riyami, A., Elaty, M. A. A., Morsi, M., Al Kharusi, H., Al Shukaily, W., \&Jaju, S. (2012). Oman world health survey: part 1 - methodology, sociodemographic profile and epidemiology of non-communicable diseases in oman. Oman medical journal, 27(5), 425.

Al Shafaee, M. A., Al-Shukaili, S., Rizvi, S. G. A., Al Farsi, Y., Khan, M. A., Ganguly, S. S., .. . Al Adawi, S. (2008). Knowledge and perceptions of diabetes in a semi-urban Omani population.BMC Public Health, 8, 249-249. https://doi.org/10.1186/1471-2458-8-249

Arksey, H., \& O'Malley, L. (2005). Scoping studies: towards a methodological framework. International journal of social research methodology, 8(1), 19-32.https://doi.org/10.1080/1364557032000119616

Australian Institute of Health and Welfare. (2014). 4.2 Chronic disease-Australia's biggest health challenge.

Barbara, A. M., Loeb, M., Dolovich, L., Brazil, K., \& Russell, M. (2012).Agreement between self-report and medical records on signs and symptoms of respiratory illness.Prim Care Respir J, 21(2), 145-152.https://doi.org/10.4104/pcrj.2011.00098

Bhandari, A., \& Wagner, T. (2006). Self-Reported Utilization of Health Care Services: Improving Measurement and Accuracy. Medical Care Research and Review, 63(2), 217-235. https://doi.org/10.1177/1077558705285298

Cerin, E., Cain, K. L., Oyeyemi, A. L., Owen, N., Conway, T. L., Cochrane, T., . . .Toftager, M. (2016). Correlates of agreement between accelerometry and self-reported physical activity.Medicine \& Science in Sports \& Exercise, 48(6), 1075-1084.https://doi.org/10.1249/MSS.0000000000000870

Chow, C. K., Teo, K. K., Rangarajan, S., Islam, S., Gupta, R., Avezum, A., . . Yusuf, S. (2013). Prevalence, Awareness, Treatment, and Control of Hypertension in Rural and Urban Communities in High-, Middle-, and Low-Income Countries. JAMA, 310(9), 959-968. https://doi.org/10.1001/jama.2013.184182

Control, C. f. D., \& Prevention.(2003). Prevalence of diabetes and impaired fasting glucose in adults--United States, 1999-2000.MMWR.Morbidity and mortality weekly report, 52(35), 833.

Cunningham, C. O., Li, X., Ramsey, K., \&Sohler, N. L. (2007). A comparison of HIV health services utilization measures in a marginalized population: self-report versus medical records. Medical care, 45(3), 264-268.https://doi.org/10.1097/01.mlr.0000250294.16240.2e

Daniels, T., Goodacre, L., Sutton, C., Pollard, K., Conway, S., \&Peckham, D. (2011). Accurate assessment of adherence: self-report and clinician report vs electronic monitoring of nebulizers. CHEST Journal, 140(2), 425-432.https://doi.org/10.1378/chest.09-3074

Downs, A., Van Hoomissen, J., Lafrenz, A., \&Julka, D. L. (2014). Accelerometer-measured versus self-reported physical activity in college students: Implications for research and practice. Journal of American College Health, 62(3), 204-212.https://doi.org/10.1080/07448481.2013.877018

Gao, K., Wu, R., Wang, Z., Ren, M., Kemp, D. E., Chan, P. K., . . . Calabrese, J. R. (2015). Disagreement between self-reported and clinician-ascertained suicidal ideation and its correlation with depression and anxiety severity in patients with major depressive disorder or bipolar disorder.Journal of psychiatric research, 60, 117-124.https://doi.org/10.1016/j.jpsychires.2014.09.011

Goldman, N., Lin, I. F., Weinstein, M., \& Lin, Y.-H. (2003). Evaluating the quality of self-reports of hypertension and diabetes. Journal of Clinical Epidemiology, 56(2), 148-154. https://doi.org/10.1016/S0895-4356(02)00580-2

Heinrich, S., Deister, A., Birker, T., Hierholzer, C., Weigelt, I., Zeichner, D., . . König, H.-H. (2011). Accuracy of self-reports of mental health care utilization and calculated costs compared to hospital records. Psychiatry research, 185(1), 261-268.https://doi.org/10.1016/j.psychres.2010.04.053

Huerta, J. M., José Tormo, M., Egea-Caparrós, J. M., Ortolá-Devesa, J. B., \& Navarro, C. (2009).Accuracy of Self-Reported Diabetes, Hypertension, and Hyperlipidemia in the Adult Spanish Population.DINO Study $\begin{array}{lllll}\text { Findings.RevistaEspa-ola de Cardiología } & \text { (English } 2 \text {, }\end{array}$ 143-152.https://doi.org/10.1016/S1885-5857(09)71532-4 
Mathers, C. D., \&Loncar, D. (2006).Projections of Global Mortality and Burden of Disease from 2002 to 2030 $\begin{array}{lllll}\text { (Projections of Global Mortality).PLoS } & \text { Medicine, } & 3(11), & \text { e442. }\end{array}$ https://doi.org/10.1371/journal.pmed.0030442

McAdams, M. A., Dam, R. M., \& Hu, F. B. (2007). Comparison of self - reported and measured BMI as correlates of disease markers in US adults. Obesity, 15(1), 188-188.https://doi.org/10.1038/oby.2007.504

McDonald, J. D. (2008). Measuring personality constructs: The advantages and disadvantages of self-reports, informant reports and behavioural assessments. Enquire, 1(1), 1-19.

McGwin, G., Owsley, C., \& Ball, K. (1998).Identifying crash involvement among older drivers: agreement between self-report and state records.Accident Analysis \& Prevention, 30(6), 781-791.https://doi.org/10.1016/S0001-4575(98)00031-1

Merkin, S. S., Cavanaugh, K., Longenecker, J. C., Fink, N. E., Levey, A. S., \&Powe, N. R. (2007). Agreement of self-reported comorbid conditions with medical and physician reports varied by disease among end-stage renal disease patients. Journal of Clinical Epidemiology, 60(6), 634-642. https://doi.org/10.1016/j.jclinepi.2006.09.003

Mohan, V., Seedat, Y. K., \&Pradeepa, R. (2013). The Rising Burden of Diabetes and Hypertension in Southeast Asian and African Regions: Need for Effective Strategies for Prevention and Control in Primary Health Care Settings.International Journal of Hypertension, 2013. https://doi.org/10.1155/2013/409083

Nishikawa, T., Edelstein, D., \& Brownlee, M. (2000). The missing link: A single unifying mechanism for diabetic complications.Kidney Int., 58, S26-S30.https://doi.org/10.1046/j.1523-1755.2000.07705.x

Norris, S. L., Nichols, P. J., Caspersen, C. J., Glasgow, R. E., Engelgau, M. M., Jack, L., . . Garfield, S. (2002). Increasing diabetes self-management education in community settings: a systematic review.American journal of preventive medicine, 22(4), 39-66.https://doi.org/10.1016/S0749-3797(02)00424-5

Paulhus, D. L., Vazire, S., Robins, R. W., Fraley, R., \& Krueger, R. F. (2007). The self-report method.Handbook of research methods in personality psychology, 1, 224-239.

Peters, M., Godfrey, C., McInerney, P., Soares, C., Hanan, K., \& Parker, D. (2015).The Joanna Briggs Institute Reviewers' Manual 2015: Methodology for JBI Scoping Reviews.

Prince, S. A., Adamo, K. B., Hamel, M. E., Hardt, J., Gorber, S. C., \& Tremblay, M. (2008). A comparison of direct versus self-report measures for assessing physical activity in adults: a systematic review. International Journal of Behavioral Nutrition and Physical Activity, 5(1), 56.https://doi.org/10.1186/1479-5868-5-56

Sakshaug, J. W., Weir, D. R., \& Nicholas, L. H. (2014). Identifying diabetics in Medicare claims and survey data: implications for health services research.BMC health services research, 14(1), 150.https://doi.org/10.1186/1472-6963-14-150

Sibley, L. M., \& Glazier, R. H. (2009). Reasons for self-reported unmet healthcare needs in Canada: a population-based provincial comparison. Healthcare Policy, 5(1), 87.https://doi.org/10.12927/hcpol.2009.20934

The Department of Health (Writer).(2017). Chronic Conditions.

Tisnado, D. M., Adams, J. L., Liu, H., Damberg, C. L., Chen, W.-P., Hu, F. A., . . Kahn, K. L. (2006). What is the concordance between the medical record and patient self-report as data sources for ambulatory care? Medical care, 44(2), 132-140.https://doi.org/10.1097/01.mlr.0000196952.15921.bf

Van den Akker, M., Van Steenkiste, B., Krutwagen, E., \&Metsemakers, J. F. (2015). Disease or no disease? Disagreement on diagnoses between self-reports and medical records of adult patients. The European journal of general practice, 21(1), 45-51.https://doi.org/10.3109/13814788.2014.907266

World Health Organization [WHO]. (2016). Global Report on Diabetes.

World Health Organization [WHO]. (2011). Global Status Report on Noncommunicable Diseases 2010. Geneva: World Health Organization.

World Health Organization [WHO]. (2013). A global brief on Hypertension.

World Health Organization [WHO]. (2015). Q\&As on Hypertension.

Wu, C.-S., Lai, M.-S., Gau, S. S.-F., Wang, S.-C., \& Tsai, H.-J. (2014). Concordance between patient self-reports and claims data on clinical diagnoses, medication use, and health system utilization in Taiwan. PloS one, 9(12), e112257.https://doi.org/10.1371/journal.pone.0112257 
Table 1. Summary of general characteristic of studies

\begin{tabular}{|c|c|c|c|c|c|c|c|c|c|}
\hline Source & Country & Study Design & $\mathbf{N}$ & $\begin{array}{l}\% \text { Fema } \\
\text { le }\end{array}$ & Aim & Age & Chronic Condition & $\begin{array}{l}\text { Self-report } \\
\text { measure }\end{array}$ & $\begin{array}{l}\text { Objective } \\
\text { measure }\end{array}$ \\
\hline $\begin{array}{l}\text { (Van den Akker, } \\
\text { Van Steenkiste, } \\
\text { Krutwagen, \& } \\
\text { Metsemakers, } \\
\text { 2015) }\end{array}$ & Netherlands & $\begin{array}{l}\text { Cross-sectiona } \\
1 \text { study }\end{array}$ & 2,893 & $51 \%$ & $\begin{array}{l}\text { Assessing the agreement } \\
\text { between } \\
\text { reporting for chronic } \\
\text { diseases and medical } \\
\text { records }\end{array}$ & $\begin{array}{l}55 \text { years } \\
\text { and older }\end{array}$ & 14 chronic diseases & questionnaire & $\begin{array}{l}\text { Electronic } \\
\text { medical record } \\
\text { system }\end{array}$ \\
\hline $\begin{array}{l}\text { (Tisnado et al., } \\
\text { 2006) }\end{array}$ & USA & cohort study & 1,270 & $54.1 \%$ & $\begin{array}{l}\text { Evaluating the association } \\
\text { between ambulatory } \\
\text { medical record and } \\
\text { patients survey }\end{array}$ & $\begin{array}{l}\text { Over age } \\
50 \text { years }\end{array}$ & $\begin{array}{l}\text { Low back pain, ischemic } \\
\text { heart disease, asthma, } \\
\text { chronic obstructive } \\
\text { pulmonary disease, and } \\
\text { diabetes }\end{array}$ & $\begin{array}{l}\text { patient self-report } \\
\text { surveys }\end{array}$ & Medical record \\
\hline $\begin{array}{lrl}(\text { Wu, } & \text { Lai, } & \text { Gau, } \\
\text { Wang, } & \& & \text { Tsai, } \\
\text { 2014) } & & \end{array}$ & Taiwan & $\begin{array}{l}\text { Cross-sectiona } \\
1 \text { study }\end{array}$ & 15,574 & $48.9 \%$ & $\begin{array}{l}\text { To evaluate the agreement } \\
\text { between claims records } \\
\text { and patients self-reports }\end{array}$ & $\begin{array}{l}12 \text { years } \\
\text { and above }\end{array}$ & $\begin{array}{l}\text { Clinical diagnoses, } \\
\text { medication use, and health } \\
\text { system utilization }\end{array}$ & $\begin{array}{l}\text { National health } \\
\text { interview survey }\end{array}$ & $\begin{array}{l}\text { National health } \\
\text { interview } \\
\text { survey }\end{array}$ \\
\hline (Gao et al., 2015) & USA & $\begin{array}{l}\text { Longitudinal } \\
\text { study }\end{array}$ & 242 & $59.1 \%$ & $\begin{array}{l}\text { To evaluate disagreement } \\
\text { between self-reported } \\
\text { suicidal ideation and } \\
\text { clinician ascertained } \\
\text { suicidal ideation }\end{array}$ & $\begin{array}{l}18 \text { years } \\
\text { and older }\end{array}$ & $\begin{array}{l}\text { Depression and anxiety } \\
\text { severity }\end{array}$ & interview & Medical record \\
\hline $\begin{array}{l}\text { (Cunningham, Li, } \\
\text { Ramsey, \&Sohler, } \\
\text { 2007) }\end{array}$ & USA & $\begin{array}{l}\text { Cross-sectiona } \\
1 \text { study }\end{array}$ & 428 & $26 \%$ & $\begin{array}{l}\text { To understand about } \\
\text { marginalized population } \\
\text { id disproportionately } \\
\text { affected by HIV }\end{array}$ & $\begin{array}{l}18 \text { years } \\
\text { and older }\end{array}$ & HIV & $\begin{array}{l}\text { Audio computer } \\
\text {-assisted } \\
\text { self-interviews }\end{array}$ & Medical record \\
\hline $\begin{array}{l}\text { (Daniels et al., } \\
\text { 2011) }\end{array}$ & UK & $\begin{array}{l}\text { Cross-sectiona } \\
1 \text { study }\end{array}$ & 78 & $44.9 \%$ & $\begin{array}{l}\text { To assess treatment } \\
\text { burden for people with } \\
\text { cystic fibrosis }\end{array}$ & $\begin{array}{l}18-60 \\
\text { years }\end{array}$ & Cystic fibrosis & questionnaire & $\begin{array}{l}\text { Questionnaire } \\
\text { and medical } \\
\text { records }\end{array}$ \\
\hline $\begin{array}{l}\text { (McAdams, Dam, } \\
\& \mathrm{Hu}, 2007)\end{array}$ & USA & $\begin{array}{l}\text { Cross-sectiona } \\
1 \text { study }\end{array}$ & 10,639 & $66.38 \%$ & $\begin{array}{l}\text { To evaluate the agreement } \\
\text { between the validity of } \\
\text { self-report and objective } \\
\text { measure for BMI }\end{array}$ & $\begin{array}{l}20 \text { years } \\
\text { and older }\end{array}$ & Body mass index (BMI) & Home survey & $\begin{array}{l}\text { National health } \\
\text { and nutrition } \\
\text { education study }\end{array}$ \\
\hline
\end{tabular}




\begin{tabular}{|c|c|c|c|c|c|c|c|c|c|}
\hline $\begin{array}{l}\text { (Sakshaug, Weir, \& } \\
\text { Nicholas, 2014) }\end{array}$ & USA & $\begin{array}{l}\text { Longitudinal } \\
\text { study }\end{array}$ & 2,028 & $55.9 \%$ & $\begin{array}{l}\text { Measuring the agreement } \\
\text { between the chronic } \\
\text { condition ware diabetes } \\
\text { algorithm for Medicare } \\
\text { claims and self-report } \\
\text { measures. }\end{array}$ & $\begin{array}{l}\text { Over age } \\
50 \text { years }\end{array}$ & diabetes & $\begin{array}{l}\text { Face to face } \\
\text { interview }\end{array}$ & $\begin{array}{l}\text { Medicare } \\
\text { claims } \\
\text { (secondary } \\
\text { data) }\end{array}$ \\
\hline $\begin{array}{l}\text { (Downs, } \\
\text { Hoomissen, } \\
\text { Lafrenz, \& Julka, } \\
\text { 2014) }\end{array}$ & USA & $\begin{array}{l}\text { Cross-sectiona } \\
1 \text { study }\end{array}$ & 77 & $48.6 \%$ & $\begin{array}{l}\text { Examining intrapersonal } \\
\text { and contextual variable }\end{array}$ & $\begin{array}{l}17-24 \\
\text { years }\end{array}$ & Physical activity & Email & $\begin{array}{l}\text { Accelerometer- } \\
\text { measured }\end{array}$ \\
\hline (Cerin et al., 2016) & $\begin{array}{l}\text { Six country } \\
\text { (a) }\end{array}$ & $\begin{array}{l}\text { Cross-sectiona } \\
1 \text { study }\end{array}$ & 3,865 & $51.9 \%$ & $\begin{array}{l}\text { Assessing factors } \\
\text { influence } \\
\text { assessment of physical } \\
\text { activity and sedentary } \\
\text { behaviour }\end{array}$ & $\begin{array}{l}18-65 \\
\text { years }\end{array}$ & Physical activity & $\begin{array}{l}\text { International } \\
\text { physical activity } \\
\text { questionnaire }\end{array}$ & $\begin{array}{l}\text { Accelerometer- } \\
\text { based }\end{array}$ \\
\hline $\begin{array}{l}\text { (Heinrich et al., } \\
\text { 2011) }\end{array}$ & Germany & $\begin{array}{l}\text { Prospective } \\
\text { Cohort study }\end{array}$ & 330 & $49.4 \%$ & $\begin{array}{l}\text { To assess the accuracy of } \\
\text { self-reports and } \\
\text { calculated for costs of } \\
\text { mental health services }\end{array}$ & $\begin{array}{l}\text { Under } 18 \\
\text { years }\end{array}$ & $\begin{array}{l}\text { Costs of mental health } \\
\text { services utilization }\end{array}$ & $\begin{array}{l}\text { telephone } \\
\text { interview }\end{array}$ & Hospital data \\
\hline $\begin{array}{l}\text { (McGwin, Owsley, } \\
\text { \& Ball, 1998) }\end{array}$ & USA & $\begin{array}{l}\text { Case-control } \\
\text { study }\end{array}$ & 278 & $49.7 \%$ & $\begin{array}{l}\text { Assessing the risk factors } \\
\text { for crash involved older } \\
\text { drivers }\end{array}$ & $\begin{array}{l}55 \text { years } \\
\text { and older }\end{array}$ & Crashes & Questionnaire & $\begin{array}{l}\text { state-recorded } \\
\text { crash }\end{array}$ \\
\hline
\end{tabular}

(a) Belgium, Denmark, Spain, Czech Republic, United Kingdom, and the United States.

Table 2. Summary of agreement between self-reporting and objective measures

\begin{tabular}{|c|c|c|c|}
\hline Source & Comparison & $\begin{array}{l}\text { Overall agreement } \\
(95 \% \mathrm{CI})\end{array}$ & Comments \\
\hline $\begin{array}{l}\text { (Van den Akker } \\
\text { et al., 2015) }\end{array}$ & $\begin{array}{l}\text { Presence of several chronic } \\
\text { diseases }\end{array}$ & $\begin{array}{l}\text { Kappa }=0.17 \\
(0.21-0.13)\end{array}$ & $\begin{array}{l}\text { Highest agreement in diabetes }(\mathrm{Kappa}=0.86,(0.83-0.87)) \text {, and lowest in rheumatoid arthritis } \\
(\mathrm{kappa}=0.17,(0.11-0.23)) .\end{array}$ \\
\hline $\begin{array}{l}\text { (Tisnado et al., } \\
\text { 2006) }\end{array}$ & Quality of ambulatory care & $\begin{array}{c}\text { Kappa }=0.5 \\
(0.5-0.6)\end{array}$ & $\begin{array}{l}\text { Agreement for counseling and referrals }(\mathrm{kappa}=0.3,(0.3-0.3)) \text {, medication use (kappa }=0.6 \text {, } \\
(0.5-0.7)) \text {, both diagnoses and clinical services delivered }(\mathrm{kappa}=0.6,(.05-0.6) .\end{array}$ \\
\hline
\end{tabular}


utilization

\begin{tabular}{|c|c|c|c|}
\hline (Gao et al., 2015) & Depression and anxiety severity & Kappa $=0.3$ & $\begin{array}{l}\text { The disagreement was positively correlated to depression severity }\left(\mathrm{R}^{2}=0.4\right) \text {, and anxiety } \\
\text { severity }\left(\mathrm{R}^{2}=0.79\right) \text { with both major depressive disorder and bipolar disorder, but was only } \\
\text { positively correlated to anxiety severity }\left(\mathrm{R}^{2}=0.46\right) \text { in bipolar disorder. }\end{array}$ \\
\hline $\begin{array}{l}\text { (Cunningham et } \\
\text { al., 2007) }\end{array}$ & $\begin{array}{l}\text { Ambulatory visits, medications } \\
\text { use and laboratory tests } \\
\text { performed }\end{array}$ & $\begin{array}{l}\text { Kappa }=0.12 \\
(0.06-0.19)\end{array}$ & Agreement for medication $(\mathrm{kappa}=0.27-0.48)$, and for laboratory tests $(\mathrm{kappa}=0.11-0.14)$ \\
\hline $\begin{array}{l}\text { (Daniels et al., } \\
\text { 2011) }\end{array}$ & $\begin{array}{l}\text { clinician report and electronic } \\
\text { monitoring of nebulizers }\end{array}$ & $\begin{array}{l}\mathrm{r}=25.3 \% \\
(18.7 \%-31.9 \%)\end{array}$ & $\begin{array}{l}\text { The agreement for clinician report }(\mathrm{r}=80 \%,(60 \%-95 \%) \text {, } \\
\text { And for electronic monitoring }(\mathrm{R}=36 \%,(5 \%-84.5 \%)\end{array}$ \\
\hline $\begin{array}{l}\text { (McAdams et al., } \\
\text { 2007) }\end{array}$ & $\begin{array}{l}\text { Height and weight and other } \\
\text { disease markers }\end{array}$ & Diff. means $=-0.56,(-0.71,-0.41)$ & $\begin{array}{l}\text { Agreement for fasting blood glucose }(\mathrm{r}=0.43) \text {, systolic blood pressure }(\mathrm{r}=0.54) \text {, and high- } \\
\text { density lipoprotein cholesterol }(\mathrm{r}=-0.53)\end{array}$ \\
\hline $\begin{array}{l}\text { (Sakshaug et al., } \\
\text { 2014) }\end{array}$ & $\begin{array}{l}\text { Healthcare utilization outcome } \\
\text { for each diabetes measures }\end{array}$ & $\begin{array}{lll}\text { Percentage of diabetes: } & 27.3 \\
\text { (Medicare claims) vs } & 21.2 \\
\text { (self-report), } \mathrm{p}<0.05 & \end{array}$ & Have high rates of healthcare spending and utilization similar to diabetics \\
\hline $\begin{array}{l}\text { (Downs et al., } \\
2014)\end{array}$ & $\begin{array}{l}\text { Intrapersonal and Contextual } \\
\text { Variables }\end{array}$ & $\begin{array}{l}-\mathrm{t} \text {-test }(\text { male })=8.89, \mathrm{p}<0.001 \\
\text {-t }- \text { test }(\text { female })=3.28, \mathrm{p}<0.01\end{array}$ & $\begin{array}{l}\text { Agreement for moderate-vigorous-intensity physical activity }(\mathrm{r}=-0.24) \text {, and social barriers }(\mathrm{r} \\
=-0.27)\end{array}$ \\
\hline $\begin{array}{l}\text { (Cerin et al., } \\
2016)\end{array}$ & $\begin{array}{l}\text { Other sociodemographic, and } \\
\text { behavioural factors }\end{array}$ & $\mathrm{r}=0.05$ to 0.37 & $\begin{array}{l}\text { Highest agreement in sedentary time }(r=0.37,(0.35-0.4) \text { and lowest in MVPA- bouts }(r= \\
0.05,(0.02-0.09) \text {. }\end{array}$ \\
\hline $\begin{array}{l}\text { (Heinrich et al., } \\
\text { 2011) }\end{array}$ & Several ICD-10 & $\begin{array}{l}\text { Kappa }=0.781 \text {, } \\
\text { and concordance correlation } \\
\text { coefficient }(\mathrm{CCC})=0.8432\end{array}$ & Agreement for $\mathrm{F} 10(\mathrm{CCC}=0.8651), \mathrm{F} 3(\mathrm{CCC}=0.7850)$, and $\mathrm{F} 10(\mathrm{CCC}=0.6180)$ \\
\hline $\begin{array}{l}\text { (McGwin et al., } \\
\text { 1998) }\end{array}$ & Crash involved elder drivers & Kappa $=0.45$ & $\begin{array}{l}\text { Significant disagreement with respect to demographic, and driving (annual mileages, days } \\
\text { per week driven) }\end{array}$ \\
\hline
\end{tabular}

Table 3. Implications of the disagreement between self-report and objective measures

\begin{tabular}{|c|c|c|}
\hline Sources & Issue & Findings \\
\hline (Van den Akker et al., 2015) & $\begin{array}{l}\text { Prevalence of } \\
\text { diseases }\end{array}$ & $\begin{array}{l}\text { The prevalence of diseases such as inflammatory joint, severe bowel disease, and malignancy/ cancer were lower by self-reporting than } \\
\text { medical records }(19 \% \text { vs } 24 \% \text {, kappa }=0.17),(10 \% \text { vs } 16 \% \text {, kappa }=0.25) \text {, and }(11 \% \text { vs } 19 \% \text {, kappa }=0.6) \text { respectively. This may result } \\
\text { in a potential increase of cost. }\end{array}$ \\
\hline
\end{tabular}




\begin{tabular}{|c|c|c|}
\hline (Tisnado et al., 2006) & $\begin{array}{l}\text { Prevalence } \\
\text { diseases }\end{array}$ & Prevalence of diseases is lower by self-reported than medical records by with range from $2 \%$ to $20 \%$. \\
\hline (Sakshaug et al., 2014) & $\begin{array}{l}\text { Prevalence } \\
\text { diabetes }\end{array}$ & $\begin{array}{l}\text { The percentage of chronic condition warehouse for diabetes is lower by self-reported measures than claims records (21.2 vs } 27.3) \text {. This } \\
\text { means the rate of healthcare spending and utilization for diabetic patients are misled. }\end{array}$ \\
\hline (McAdams et al., 2007) & $\begin{array}{l}\text { Prevalence } \\
\text { obesity }\end{array}$ & $\begin{array}{l}\text { BMI based on technician measurements }(25.52 \mathrm{~kg} / \mathrm{m} 2) \text { was higher than BMI based on self-reported. This difference was small but it } \\
\text { increased with increasing average values of these measures. This leads to a greater tendency for self-reported BMI to underestimate true } \\
\text { BMI with increasing adiposity. }\end{array}$ \\
\hline (Gao et al., 2015) & $\begin{array}{l}\text { Prevalence } \\
\text { suicide }\end{array}$ & $\begin{array}{l}\text { The prevalence of major depressive disorder was } 5.8 \% \text { by measuring self-reported, whereas it was } 22.4 \% \text { by using clinician ascertained. } \\
\text { In addition, the prevalence of bipolar disorder was higher by using clinician ascertained (35.9\%) than by measuring self-reported (18.4\%). } \\
\text { This leads to higher prevalence of depression disorder than reported. }\end{array}$ \\
\hline (Downs et al., 2014) & $\begin{array}{l}\text { Level of physical } \\
\text { activity }\end{array}$ & $\begin{array}{l}\text { Students have less level of physical activity than their self-reporting: about } 66.7 \% \text { of them who thought they have sufficient physical } \\
\text { activity, where only } 33.8 \% \text { of students have enough level of physical activity. This implies students are over } 2 \text { times more sedentary than } \\
\text { reported. }\end{array}$ \\
\hline (Cerin et al., 2016) & $\begin{array}{l}\text { Sedentary } \\
\text { behaviour (time) }\end{array}$ & $\begin{array}{l}\text { Sitting time is less by } 3 \text { hours daily by self-reported than accelerometry- based sedentary behaviour. This means student are more } \\
\text { sedentary than reported. }\end{array}$ \\
\hline (Heinrich et al., 2011) & $\begin{array}{l}\text { Costs of mental } \\
\text { health services }\end{array}$ & Costs were higher by self-reports than based on hospital records (15 EUR [95\% CI -434 to 405]). \\
\hline (McGwin et al., 1998) & $\begin{array}{l}\text { Risk factor for } \\
\text { crashes }\end{array}$ & $\begin{array}{l}\text { The OR for a useful field of view in elderly drivers was over four times larger than that obtained from self-report (13.7 vs } 3.4 \text { ), which } \\
\text { impact on vision during driving increasing risk of car accident. }\end{array}$ \\
\hline (Daniels et al., 2011) & $\begin{array}{l}\text { Assessment } \\
\text { Adherence }\end{array}$ & $\begin{array}{l}\text { The median adherence level was at } 80 \% \text { (interquartile range, } 57.5 \%-95 \% \text { ) by self-reported measures, whereas median adherence was at } \\
36 \% \text { (interquartile range, } 5 \%-84.5 \% \text { ) by using electronic monitoring. }\end{array}$ \\
\hline (Cunningham et al., 2007) & $\begin{array}{l}\text { Health services } \\
\text { utilization }\end{array}$ & $\begin{array}{l}\text { Optimal ambulatory care utilization (more than or equal } 2 \text { visits for } 6 \text { months) for HIV cases was } 53.5 \% \text { by measuring from the medical } \\
\text { records, where this care utilization was } 87.6 \% \text { by using self-report. This makes difficult to know the benefit of this care utilization. }\end{array}$ \\
\hline (Wu et al., 2014) & Health insurance & $\begin{array}{l}\text { The prevalence of psychiatric, heart diseases and arthritis is lower by self-reported than claims records (1.6 vs } 6.8) \text {, }(3.9 \text { vs } 8.2) \text {, and ( } 3.3 \\
\text { vs } 7.0) \text { respectively. This means the lower prevalence by self-reported than claim records lead to misleading in planning in health } \\
\text { insurance. }\end{array}$ \\
\hline
\end{tabular}

\section{Copyrights}

Copyright for this article is retained by the author(s), with first publication rights granted to the journal.

This is an open-access article distributed under the terms and conditions of the Creative Commons Attribution license (http://creativecommons.org/licenses/by/4.0/). 